\title{
Different Requirements for cAMP Response Element Binding Protein in Positive and Negative Reinforcing Properties of Drugs of Abuse
}

\author{
Carrie L. Walters and Julie A. Blendy \\ Department of Pharmacology, Center for Neurobiology and Behavior, University of Pennsylvania, Philadelphia, \\ Pennsylvania 19104
}

Addiction is a complex process that relies on the ability of an organism to integrate positive and negative properties of drugs of abuse. Therefore, studying the reinforcing as well as aversive components of drugs of abuse in a single model system will enable us to understand the role of final common mediators, such as cAMP response element-binding protein (CREB), in the addiction process. To this end, we analyzed mice with a mutation in the $\alpha$ and $\Delta$ isoforms of the CREB gene. Previously we have shown that $\mathrm{CREB}^{\alpha \Delta}$ mutant mice in a mixed genetic background show attenuated signs of physical dependence, as measured by the classic signs of withdrawal. We have generated a uniform genetically stable F1 hybrid (129SvEv/C57BL/6) mouse line harboring the CREB mutation. We have found the functional activity of CREB in these F1 hybrid mice to be dramatically reduced compared with their wild-type littermates. These mice maintain a reduced withdrawal phenotype after

Many drugs of abuse, administered repeatedly over time, cause tolerance and physical dependence. These adaptations have been correlated with changes in the intracellular cAMP signal transduction cascade. Elements of the cascade found to be altered include G-proteins, adenylate cyclase, protein kinase A (PKA), and its target cAMP response element-binding protein (CREB) (Nestler et al., 1994; Wang et al., 1996; Wang and Gintzler, 1997; Chakrabarti et al., 1998). The activity of CREB is regulated by phosphorylation, and both morphine and cocaine have been shown to alter this state of the CREB protein. Although cocaine and morphine have different primary sites of action in the brain, there is a growing body of evidence suggesting that CREB may serve as a final common mediator in the ultimate expression of both positive and negative reinforcing properties of there drugs.

In addition to the physical symptoms of withdrawal, negative motivational properties of drugs of abuse clearly contribute to the overall dysphoria experienced by an animal (Gellert and Sparber, 1977; Stinus et al., 1990). This aversive motivational component seems to play an important role in the maintenance of addictive behavior. Different neuronal circuitry may be involved in the manifestation of the physical signs of opiate withdrawal and the

Received July 2, 2001; revised Sept. 5, 2001; accepted Sept. 11, 2001.

This work was supported by National Institute on Drug Abuse Grant DA-1164901A2. We thank Alana Conti and Misty Godfrey for technical assistance and Drs. Laura Peoples and Michelle Page for critically reading this manuscript.

Correspondence should be addressed to Julie A. Blendy, Department of Pharmacology, 125 John Morgan Building, 3620 Hamilton Walk, Philadelphia, PA 191046084. E-mail: blendy@pharm.med.upenn.edu.

Copyright (ㄷ) 2001 Society for Neuroscience $\quad 0270-6474 / 01 / 219438-07 \$ 15.00 / 0$ chronic morphine. We are now poised to examine a number of complex behavioral phenotypes related to addiction in a well defined CREB-deficient mouse model.

We demonstrate that the aversive properties of morphine are still present in CREB mutant mice despite a reduction of physical withdrawal. On the other hand, these mice do not respond to the reinforcing properties of morphine in a conditioned place preference paradigm. In contrast, CREB mutant mice demonstrate an enhanced response to the reinforcing properties of cocaine compared with their wild-type controls in both conditioned place preference and sensitization behaviors. These data may provide the first paradigm for differential vulnerability to various drugs of abuse.

Key words: mice; CREB; morphine; cocaine; conditioned place preference; sensitization motivational signs of opiate withdrawal. The locus coeruleus (LC) is commonly associated with the somatic signs of withdrawal, whereas the nucleus accumbens (NAc) is associated with the reinforcing properties of opiates (Goeders et al., 1984; Vaccarino et al., 1985) as well as the aversive-dysphoric component of opiate withdrawal (Koob et al., 1989, 1992). However, in both the LC and NAc, the cAMP pathway is upregulated after chronic morphine, suggesting a similar biochemical mechanism underlying physical withdrawal and aversion to morphine (Duman et al., 1988; Nestler and Tallmn, 1988; Terwilliger et al., 1991; Matsuoka et al., 1994). Although CREB is critical in the manifestation of the physical signs of opiate withdrawal, its role in mediating the aversive properties of the drug is not known.

Whereas negative properties of drugs may contribute to the development of addiction, initial drug use may be motivated by the positive affective state produced by the drug (Koob, 1996). Positive reinforcing properties of cocaine and morphine produce some of their acute effects via similar actions on the mesolimbic and mesocortical dopamine systems (Nestler et al., 1994). Identical changes in synaptic regulation of dopamine cells in the mesolimbic system (the ventral tegmental area) are seen after chronic treatment with either cocaine or morphine (Bonci and Williams, 1996). However, although acute administration of cocaine has been shown to induce CREB phosphorylation in the striatum (Kano et al., 1995), acute morphine administration decreases the phosphorylation of CREB, and chronic morphine administration attenuates this affect (Guitart et al., 1992). Thus, the contribution of CREB to the acute positive reinforcing properties of cocaine and morphine remains to be elucidated. 
Progressive enhancement of the locomotor stimulatory effects of drugs is referred to as behavioral sensitization (Robinson and Becker, 1986; Stewart and Badiani, 1993). The augmentation of this behavioral response has been reported to occur after a single injection and to be maintained for several months after cessation of intermittent drug treatment (Robinson and Becker, 1986) (for review, see Post and Weiss, 1988; Kalivas and Stewart, 1991). It is of interest that the repeated administration of psychomotor stimulants such as cocaine, and the augmented locomotor hyperactivity it produces, can facilitate acquisition of a conditioned place preference or drug self-administration behavior (Lett, 1989; Piazza et al., 1989; Horger et al., 1990). Hence, processes underlying behavioral sensitization may reflect similar mechanisms and/or changes in the brain responsible for rewarding properties of drugs. Therefore, to investigate the role of CREB in a behavior that has been directly related to drug seeking and reinstatement (Shippenberg and Heidbreder, 1995; De Vries et al., 1998), we examined sensitization to the locomotor effects induced by repeated cocaine administration in $\mathrm{CREB}^{\alpha \Delta}$ mutant mice.

\section{MATERIALS AND METHODS}

\section{Subjects}

Animals were housed in a $21^{\circ} \mathrm{C}$ humidity-controlled Association for Assessment and Accreditation of Laboratory Animal Care-approved animal care facility with food and water available ad libitum. The rooms were on a $12 \mathrm{hr}$ light/dark cycle (lights on at 7:00 A.M.). All experiments were performed during the light cycle from 9:00 A.M. to 2:00 P.M.

$\mathrm{CREB}^{\alpha \Delta}$ mice are maintained as F1 hybrids of 129 SvEvTac:C57BL/6. The parental strains for this hybrid line have been backcrossed with vendor-supplied wild-type strains for several generations. The CREB $^{\alpha \Delta} 129$ SvEvTac strain is currently backcrossed to N10, and the CREB $^{\alpha \Delta}$ C57BL/6 strain is currently backcrossed to N12. For all experiments, mutants and wild-type controls are obtained from crossing heterozygote CREB $^{\alpha \Delta}$ 129SvEvTac N10 with heterozygote CREB $^{\alpha \Delta}$ C57BL/6 N12. This breeding scheme allows us to rigorously control for a uniform genetic background of experimental animals over time and is in agreement with the recommendations of the Branbury Conference on Genetic Background in Mice (Silva et al., 1997).

\section{$C R E B^{\alpha \Delta}$ PCR genotyping}

Mice were genotyped by PCR analysis. Briefly, tail biopsies were digested in $0.2 \mathrm{ml}$ of NID buffer $(50 \mathrm{~mm} \mathrm{KCl}, 10 \mathrm{~mm}$ Tris-HCl, $\mathrm{pH} 8.3,2 \mathrm{~mm}$ $\mathrm{MgCl}_{2}, 0.1 \mathrm{mg} / \mathrm{ml}$ gelatin, $0.45 \% \mathrm{NP}-40$, and $0.45 \%$ Tween 20$)$ and 1.2 $\mu \mathrm{l}$ proteinase $\mathrm{K}(10 \mathrm{mg} / \mathrm{ml})$ overnight at $56^{\circ} \mathrm{C}$, and $1 \mu \mathrm{l}$ of DNA was used directly in a PCR reaction. For genotyping CREB ${ }^{\alpha \Delta}$ mice, the following conditions and PCR primers were used: $95^{\circ} \mathrm{C} ; 60 \mathrm{sec} / 62^{\circ} \mathrm{C} ; 60 \mathrm{sec} / 72^{\circ} \mathrm{C}$; $90 \mathrm{sec}$, for 32 cycles. NEO primer: GGACAGGTCGGTCTTGAGAAAA, $5^{\prime} \mathrm{CREB} \alpha \Delta$ primer: CAGGGACCATTCCTCATTTCCT, and 3'CREB $\alpha \Delta$ primer: GCTGGGCTTGAACTGTCATTTG.

\section{Electric mobility shift assays}

Protein extracts were prepared by homogenizing various regions of brain tissues from wild-type and CREB ${ }^{\alpha \Delta}$ mutant mice in extraction buffer (20 mM HEPES, pH 7.6, $125 \mathrm{~mm} \mathrm{NaCl}, 5 \mathrm{~mm} \mathrm{MgCl}_{2}, 0.2 \mathrm{~mm}$ EDTA, $12 \%$ glycerol, 0.1 mM EGTA, 0.1\% NP-40, 5 mм DTT, 0.5 mм PMSF, $1 \mathrm{~mm}$ $\mathrm{ZnCl}_{2}, 1 \mathrm{~mm} \mathrm{NaF}, 2 \mu \mathrm{g} / \mathrm{ml}$ leupeptin, and $4 \mu \mathrm{g} / \mathrm{ml}$ aprotinin). The homogenized samples were sonicated briefly and centrifuged at 13,000 $\mathrm{rpm}$ for $10 \mathrm{~min}$. Five micrograms of protein were incubated with $1 \mu \mathrm{g}$ of dIdC and radiolabeled CRE oligonucleotide 5'-AGA GAT TGC CTG ACG TCA GAG AGC TAG-3' (Promega, Madison, WI) in binding buffer (10 mм HEPES, pH 7.9, $80 \mathrm{~mm} \mathrm{KCl,} 50 \mu \mathrm{M}$ EDTA, $6 \%$ glycerol, $1 \mathrm{~mm} \mathrm{DTT}$, and $1 \mathrm{~mm} \mathrm{MgCl}_{2}$ ) for $15 \mathrm{~min}$ at room temperature.

\section{Conditioned place aversion}

The negative motivational properties of opiate withdrawal were investigated using a conditioned place aversion paradigm. Place conditioning boxes consisted of two sides $(20 \times 20 \times 20 \mathrm{~cm})$ : one with stripes on the walls and a metal grid and the other with gray walls and plastic flooring. A partition separates the two sides with an opening that allows access to either side of the chamber, and this partition can be closed off for pairing days. Animals were subcutaneously implanted with one morphine pellet (75 mg; NIDA Drug Supply, Research Triangle Park, NC) under light halothane anesthesia to induce morphine dependence in these animals. The conditioned place aversion experiment took place in the following manner.

Preconditioning phase. Two days after the pellet implant, mice were placed in one side of the box and allowed to roam freely between the sides for $900 \mathrm{sec}$. Time spent in each side was recorded, and these data were used to separate animals into groups with approximately equal biases for each side.

Conditioning phase. After the preconditioning phase, there were two pairing days with an intraperitoneal injection given on each day. Animals were paired with either a saline injection $(0.9 \%$ sodium chloride $)$ on both sides or with the opiate antagonist naloxone $(1 \mathrm{mg} / \mathrm{kg}$; Sigma, St. Louis, $\mathrm{MO})$ on one side and saline on the other side. They were then confined to one side of the box for $30 \mathrm{~min}$. Naloxone-paired sides were randomized among all groups.

Testing phase. On test day, all animals received saline injections and were allowed to roam freely between sides. Time spent in each side was recorded, and the data are expressed as time spent in the drug-paired side minus time spent in the saline-paired side.

\section{Conditioned place preference (morphine and cocaine)}

The same place preference boxes from the conditioned place aversion experiment were used to determine morphine and cocaine preference. A similar paradigm was used for the morphine and the cocaine place preference paradigms. Morphine (NIDA Drug Supply) was administered at a dose of $5 \mathrm{mg} / \mathrm{kg}$, and cocaine (NIDA Drug Supply) was administered at either 5 or $10 \mathrm{mg} / \mathrm{kg}$. The conditioned place preference experiments took place in the following manner.

Preconditioning phase. On day 1 , animals were tested in a preconditioning day paradigm similar to the preconditioning phase in the place aversion experiment. Data from the preconditioning day were used to separate the animals into groups of approximately equal bias.

Conditioning phase. Animals were paired for $8 \mathrm{~d}$ with the saline group receiving saline in both sides of the boxes, and drug groups receiving morphine or cocaine on one of the sides and saline on the opposite side. Drug-paired sides were randomized among all groups ( $n=6$ per group).

Test phase. On the test day, animals were all given a saline injection and allowed to roam freely between the two sides. Time spent on each side was recorded, and data were expressed as time spent on drug-paired side minus time spent on saline-paired side.

\section{Locomotor activity}

Locomotor activity was analyzed in a "home cage" activity monitoring system (MedAssociates, St. Albans, VT). The testing cage was placed in a photobeam frame $(30 \times 24 \times 8 \mathrm{~cm})$ with two levels of sensors arranged in an 8 beam array strip with 1.25 inch spacing. Mice were injected intraperitoneally with a dose of cocaine $(10.0$ or $20.0 \mathrm{mg} / \mathrm{kg} ; n=6$ per group) and individually placed in the cages. Beam break data were read into MedAssociates personal computer-designed software and monitored at 5 min intervals for $30 \mathrm{~min}$.

Behavioral sensitization. To habituate the mice to the test environment, basal locomotor activity was measured on days 1-3. Animals were given an intraperitoneal injection of saline and placed in the test cages for 30 $\mathrm{min}$, and locomotor activity was recorded in $5 \mathrm{~min}$ bins. From days 4-9, mice were injected with cocaine $(20 \mathrm{mg} / \mathrm{kg}$; NIDA Drug Supply) or saline and placed in the chambers for $30 \mathrm{~min}$, and locomotor activity was recorded in $5 \mathrm{~min}$ bins. It is during this period that sensitization to the locomotor-activating effects of cocaine develop. This development was followed by a $21 \mathrm{~d}$ drug-free period. The expression of behavioral sensitization was tested on day 30 when the animals were administered a dose of cocaine that was half of the dose they received during the development phase $(10 \mathrm{mg} / \mathrm{kg})$.

\section{Statistics}

For all data, statistical analyses were performed using StatView. Conditioned place preference data were analyzed with ANOVAs using a Bonferroni-Dunn post hoc test. Sensitization development data were 
Figure 1. CRE-binding activity is rebinding activity was analyzed by EMSA. Perfect consensus CRE oligonucleotides and cell extracts obtained from various regions of wild-type and $\mathrm{CREB}^{\alpha \Delta} \mathrm{mu}-$ tant brains including thalamus, posterior cortex, striatum, hippocampus, cerebellum, and frontal cortex (lanes 1-6, respectively) were examined. duced in $\mathrm{CREB}^{\alpha \Delta}$ mutant mice. CRE
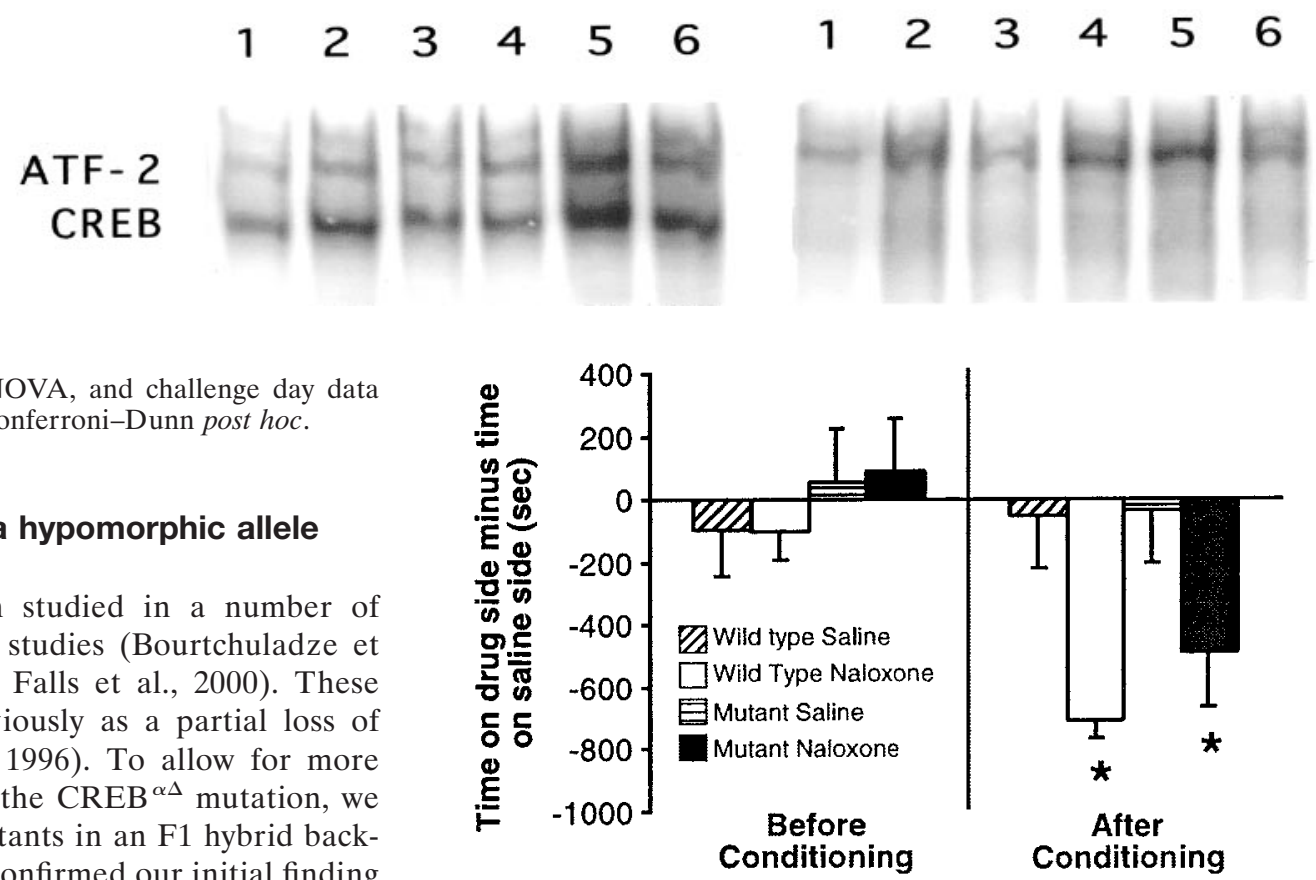

analyzed with a repeated measures ANOVA, and challenge day data were analyzed with ANOVAs using a Bonferroni-Dunn post hoc.

\section{RESULTS}

\section{Functional characterization of a hypomorphic allele of CREB}

$\mathrm{CREB}^{\alpha \Delta}$ mutant mice have been studied in a number of neurophysiological and behavioral studies (Bourtchuladze et al., 1994; Maldonado et al., 1996; Falls et al., 2000). These animals have been described previously as a partial loss of function mutation (Blendy et al., 1996). To allow for more thorough behavioral evaluation of the $\mathrm{CREB}^{\alpha \Delta}$ mutation, we have now propagated CREB ${ }^{\alpha \Delta}$ mutants in an F1 hybrid background $(129 \mathrm{SvEv} / \mathrm{C} 57 \mathrm{Bl} / 6)$ and reconfirmed our initial finding of attenuated physical symptoms of withdrawal (global withdrawal wild-type, $141.25 \pm 13.77$ CREB $^{\alpha \Delta}$ mutant, $104.75 \pm$ 2.78; Student's $t$ test, $p<0.05$ ). In addition, we examined other characteristics of this F1 hybrid line and found that the CREB $\beta$ isoform and cAMP response element modulatory protein (CREM) mRNA levels are upregulated in these mice (data not shown), a result comparable with that seen in the original mutation in a mixed genetic background (Hummler et al., 1994; Blendy et al., 1996). Furthermore, the amount of functional CRE-binding activity remaining in mice homozygous for this hypomorphic $\mathrm{CREB}^{\alpha \Delta}$ allele was examined using electrophoretic mobility shift assays (EMSAs). Perfect consensus CRE oligonucleotides and cell extracts obtained from discrete brain regions from wild-type and $\mathrm{CREB}^{\alpha \Delta}$ mutant mice, including frontal and posterior cortex, hippocampus, thalamus, striatum, and cerebellum were examined. In all tissues, two major CRE binding complexes were observed. Previous studies with EMSAs using specific antibodies against CREB, activating transcription factor-2 (ATF-2), and ATF-1 (Upstate Biotechnology, Lake Placid, NY) established that these complexes contain CREB and ATF-2 (data not shown). Levels of ATF-2 binding are similar in wild-type and CREB ${ }^{\alpha \Delta}$ mutant mice. However, levels of CREB binding in the $\mathrm{CREB}^{\alpha \Delta}$ mutant mice are dramatically reduced (Fig. 1). These data indicate that the upregulated CREB $\beta$ isoform present in the $\mathrm{CREB}^{\alpha \Delta}$ mutant mice does not efficiently bind a perfect consensus CRE element and that total CREB binding to its consensus target site is reduced by $>90 \%$ in F1 hybrid $\mathrm{CREB}^{\alpha \Delta}$ mutant mice.

\section{Conditioned place aversion to opiate withdrawal}

To assess the negative motivational behaviors induced by morphine withdrawal in $\mathrm{CREB}^{\alpha \Delta}$ mutant mice, we used a twochamber place-conditioning procedure. Preconditioning day data revealed no significant differences in time spent on either side of the chamber expressed as time on striped side minus time on
Figure 2. $\mathrm{CREB}^{\alpha \Delta}$ mutant mice show similar conditioned place aversion to naloxone-precipitated morphine withdrawal as their wild-type littermates. The left side of the graph shows that no initial preference for either side exists for any of the experimental groups. The right side of the graph shows that both the wild-type and $\mathrm{CREB}^{\alpha \Delta}$ mutant mice that received naloxone avoided the side paired with naloxone. ${ }^{*} p<0.05$ from corresponding saline group ( $n=6$ per group).

plain side (Fig. 2) $\left(F_{(3,22)}=0.492\right.$; not significant). These data confirm that no initial bias to either side existed. However, both wild-type and $\mathrm{CREB}^{\alpha \Delta}$ mutant animals showed a significant aversion to the side paired with naloxone (Fig. 2) $\left(F_{(3,22)}=5.954\right.$, ${ }^{*} p<0.05$ from saline group).

\section{Morphine-conditioned place preference}

To assess the rewarding properties of morphine in $\mathrm{CREB}^{\alpha \Delta}$ mutant mice, we used a conditioned place preference paradigm. Preconditioning data revealed no significant differences in time spent on either side of the chamber expressed as time on striped side minus time on plain side (Fig. 3) $\left(F_{(3,24)}=\right.$ 0.090; not significant). The wild-type morphine group showed a significant preference for the morphine-paired side, whereas the $\mathrm{CREB}^{\alpha \Delta}$ mutant morphine group did not show a preference for either side (Fig. 3) $\left(F_{(3,24)}=3.566 ;{ }^{*} p<0.05\right.$ from saline group).

\section{Cocaine-conditioned place preference}

To assess the rewarding properties of cocaine in $\mathrm{CREB}^{\alpha \Delta}$ mutant mice, we once again used the conditioned place preference paradigm. Preconditioning day data revealed no significant differences in time spent on either side of the chamber expressed as time on striped side minus time on plain side (Fig. 4) $\left(F_{(3,20)}=\right.$ 0.106; not significant). Two doses of cocaine ( 5 and $10 \mathrm{mg} / \mathrm{kg}$ ) were used in this paradigm. Wild-type mice show a preference for the 5 and $10 \mathrm{mg} / \mathrm{kg}$ cocaine paired sides, but this only reaches statistical significance at the $10 \mathrm{mg} / \mathrm{kg}$ dose. However, $\mathrm{CREB}^{\alpha \Delta}$ 


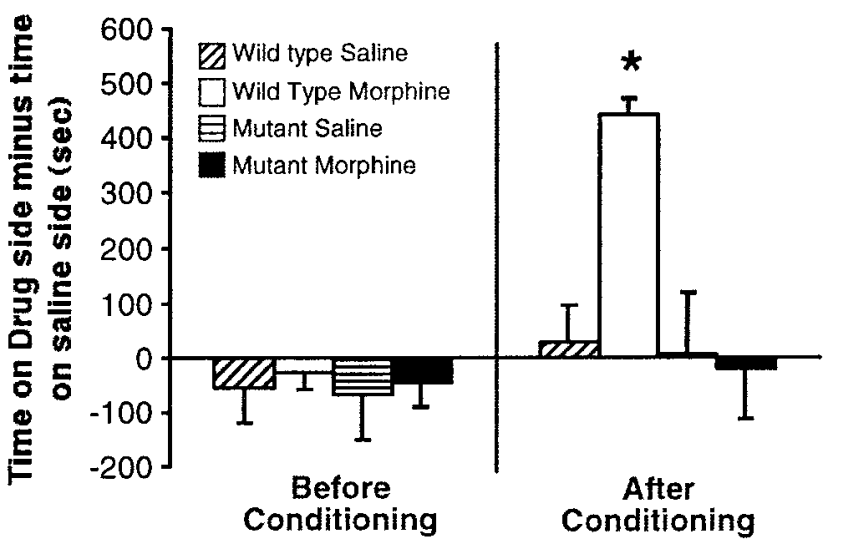

Figure 3. $\mathrm{CREB}^{\alpha \Delta}$ mutant mice do not exhibit morphine-conditioned place preference. The left side of the graph shows no initial preference for either side exists for any of the experimental groups. The right side of the graph shows that the wild-type mice administered morphine prefer the side paired with morphine, whereas the $\mathrm{CREB}^{\alpha \Delta}$ mutant mice administered morphine show no preference to either the side paired with morphine or the saline-paired side. ${ }^{*} p<0.05$ from saline group $(n=6$ per group).

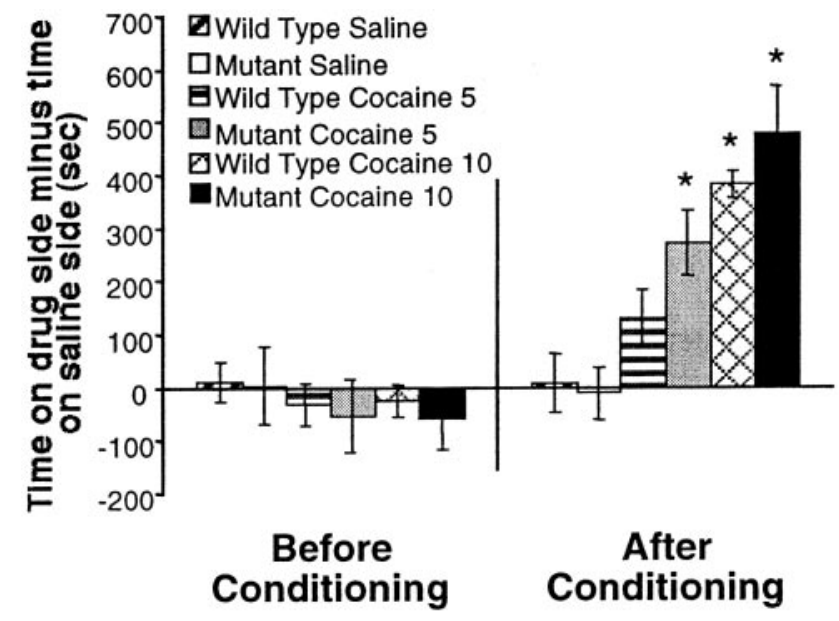

Figure 4. $\mathrm{CREB}^{\alpha \Delta}$ mutant mice exhibit heightened cocaine-conditioned place preference. The left side of the graph shows that no initial preference for either side exists for any of the experimental groups. The right side of the graph shows that $\mathrm{CREB}^{\alpha \Delta}$ mutant mice show a preference to the side paired with $5 \mathrm{mg} / \mathrm{kg}$ cocaine, whereas their wild-type littermates do not show a preference for the side paired with the same dose of cocaine. However, at a dose of $10 \mathrm{mg} / \mathrm{kg}$ cocaine, both wild-type and mutant mice show significant preference for the cocaine-paired side. ${ }^{*} p<$ 0.05 from saline group ( $n=6$ per group).

mutant mice showed a significant preference at both doses (Fig. 4) $\left(F_{(3,20)}=4.231 ;{ }^{*} p<0.05\right.$ from saline group). Furthermore, an acute locomotor activity study revealed no differences in number of ambulations between wild-type and $\mathrm{CREB}^{\alpha \Delta}$ mutant mice at these doses of cocaine ( 5 and $10 \mathrm{mg} / \mathrm{kg}$; data not shown). These data indicate that the differences in preference are not attributable to an increase in locomotor activity in the mutant mice in this paradigm.

\section{Cocaine sensitization}

To further examine the effects of chronic cocaine administration in $\mathrm{CREB}^{\alpha \Delta}$ mutant mice, a behavioral sensitization paradigm was used. Animals that received $20 \mathrm{mg} / \mathrm{kg}$ of cocaine on days 4-9 exhibited more ambulations than animals that received saline. There were no significant differences in the number of ambulations between $\mathrm{CREB}^{\alpha \Delta}$ mutant mice and their wild-type littermates when administered $20 \mathrm{mg} / \mathrm{kg}$ cocaine. However, on day 30 , after a $21 \mathrm{~d}$ cocaine-free period, $\mathrm{CREB}^{\alpha \Delta}$ mutant mice exhibit significantly more ambulations at a dose of $10 \mathrm{mg} / \mathrm{kg}$ than their wild-type littermates at the same dose (Fig. 5) $\left(F_{(3,20)}=33.275\right.$; $* p<0.05$ from wild type).

\section{DISCUSSION}

Understanding the molecular mechanisms of addiction has been aided by the derivation of genetically altered mice (Miner et al., 1995; Giros et al., 1996; Maldonado et al., 1996; Rubinstein et al., 1997; Phillips et al., 1998; Sora et al., 1998). However, the validity of these mice as models of disease relies on the reproducibility of behavioral phenotypes. Previously we have shown that $\mathrm{CREB}^{\alpha \Delta}$ mutant mice in a mixed genetic background (129Sv/C57BL6/ FVBN) exhibit attenuated signs of physical dependence (Maldonado et al., 1996). This phenotype is maintained in our genetically stable and uniform F1 hybrid mouse line. Because a lack of CREB results in attenuated somatic signs in these mice, we would predict a corresponding decrease in the negative motivational aspects of morphine withdrawal if these behaviors result from activation of the same molecular pathway. However, despite the reduction of somatic signs of withdrawal, $\mathrm{CREB}^{\alpha \Delta}$ mice demonstrate strong aversion to opiate withdrawal in a conditioned place aversion paradigm.

The neural substrates for the physical signs of opiate withdrawal have been well studied and are localized to sites such as the periaqueductal gray and locus coeruleus (Koob et al., 1992). In contrast, the neural substrates for the motivational aspects of opiate withdrawal may be primarily localized to the opiate receptors in the nucleus accumbens and more recently, the bed nucleus of the stria terminalis (Delfs et al., 2000). Hence, the differential response in CREB-deficient mice in somatic versus aversive signs of withdrawal may reflect a different requirement for CREB in specific brain regions. CREB is considered a ubiquitous protein, however, detailed immunohistochemical analysis of distribution patterns throughout the brain have not been determined. Our results indicate that the residual amount of CREB present throughout the $\mathrm{CREB}^{\alpha \Delta}$ mutant mice may be sufficient in some brain regions to allow the expression of negative motivational aspects of morphine withdrawal but not for the expression of somatic signs.

To further investigate the involvement of CREB in addictive behaviors, we used conditioned place preference to examine whether deletion of CREB would alter the positive reinforcing properties of morphine. Previous studies suggest that a similar neural substrate underlies the aversive and reinforcing properties of opiates (Koob et al., 1989). Hence, we might expect that $\mathrm{CREB}^{\alpha \Delta}$ mutant mice would show morphine-conditioned place preference because they show opiate withdrawal-induced place aversion. Surprisingly, $\mathrm{CREB}^{\alpha \Delta}$ mutant mice do not exhibit a preference to the morphine paired side of the conditioning chamber, indicating a lack of reinforcing properties of morphine in these animals. These studies demonstrate that a decrease in CREB protein does not affect aversion, but that this CREB deficiency does impair the reinforcing effects of morphine. Together, these results suggest that separate molecular mechanisms and/or neuronal circuitry are used for these distinct behavioral responses. 


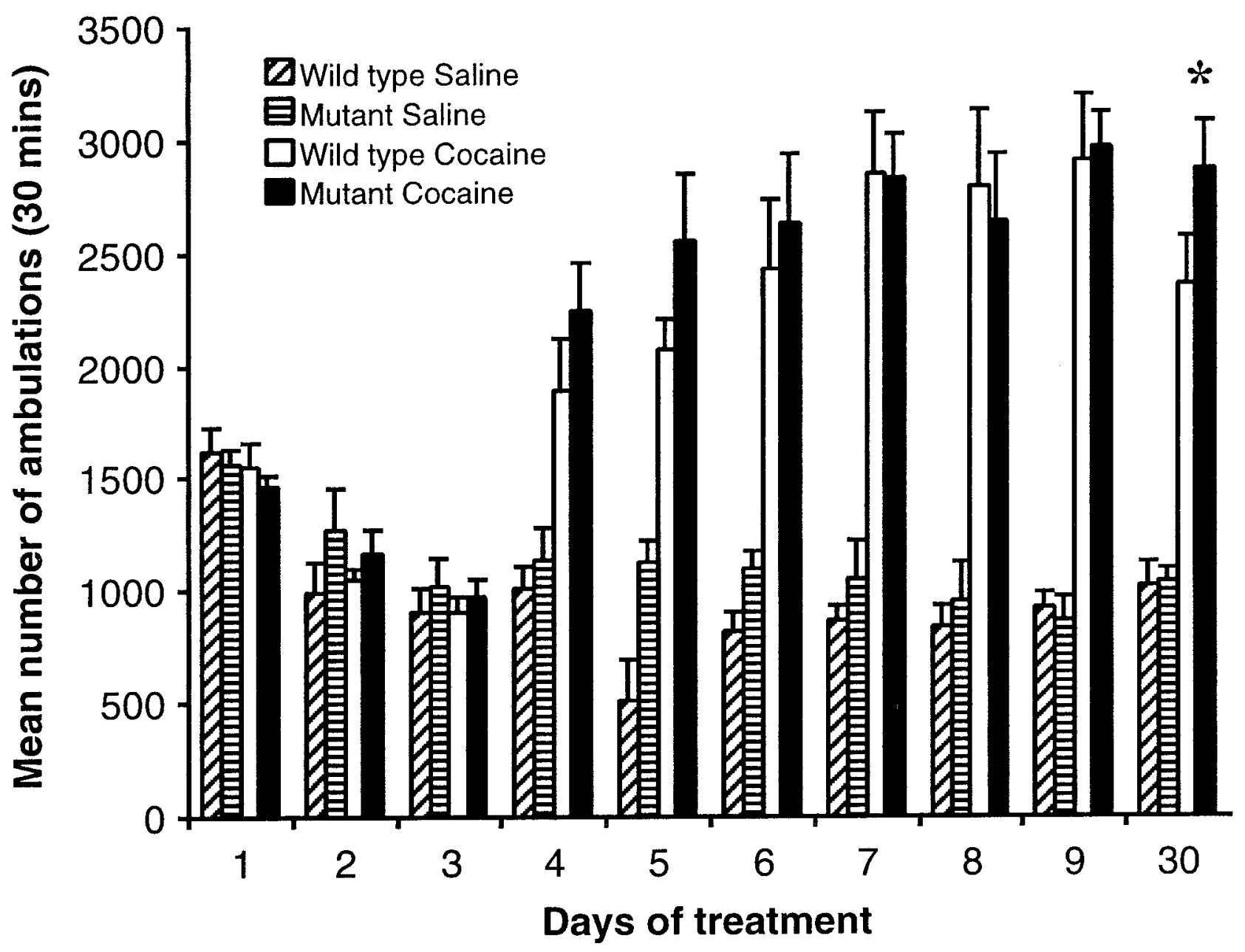

Figure 5. Behavioral sensitization to cocaine in $\mathrm{CREB}^{\alpha \Delta}$ mutant mice. There are no significant differences between the wild-type and CREB ${ }^{\alpha \Delta}$ mutant mice during the habituation period (days 1-3; saline injections only). Cocaine-treated mice all exhibit significantly more ambulations than saline-treated mice during the development of sensitization (days 4-6); however, there are no significant differences between cocaine-treated wild-type and CREB ${ }^{\alpha \Delta}$ mutant mice. Although both groups exhibit sensitization on the challenge day, the CREB ${ }^{\alpha \Delta}$ mutant mice show significantly more ambulations than wild-type mice. ${ }^{*} p<0.05$ from wild-type cocaine group ( $n=6$ per group).

To determine whether these effects of the CREB deficiency are specific to the reinforcing properties of morphine or are extended to other classes of drugs of abuse, we examined the effects of cocaine in the $\mathrm{CREB}^{\alpha \Delta}$ mutant mice. Cocaine shares many cellular targets with morphine. Both drugs produce some of their acute reinforcing properties via similar actions on the mesolimbic and mesocortical dopamine systems (Nestler et al., 1994). Identical changes in synaptic regulation of dopamine cells in the mesolimbic system (the ventral tegmental area) are seen after chronic treatment with either cocaine or morphine (Bonci and Williams, 1996). We used conditioned place preference to evaluate cocaine in the same paradigm that was used for morphine. In striking contrast to the situation with morphine, CREB-deficient mice show an augmented response to the reinforcing properties of cocaine in this paradigm. These data parallel those of Carlezon et al. (1998), who showed that overexpression of a dominantnegative mutant of CREB in the NAc, which effectively decreases CREB activity in this area, increases the rewarding effects of cocaine.

Further characterization of the cocaine response was examined in a behavioral sensitization paradigm. In this study, $\mathrm{CREB}^{\alpha \Delta}$ mice habituated to a novel environment as did their wild-type controls, and no significant differences are seen after the first dose of cocaine. Sensitization appears to develop in a similar manner in wild-type and CREB-deficient mice during the course of the repeated cocaine injections. The expression of sensitization was elicited by injecting half the dose of cocaine used to develop sensitization and measured after a 3 week drug-free period. In this case, CREB-deficient mice demonstrate a significant increase in locomotor activity compared with their wild-type controls. However, the interpretation of an increase in sensitization is questionable because both groups have developed sensitization according to the basic definition: lower doses of the drug produce effects previously observed after a single acute administration of a higher drug dose (Goeders et al., 1997). Further analysis of complete dose-response relationships between cocaine and alterations in locomotor activity will be required to fully assess the role of CREB in behavioral sensitization.

The different requirement for CREB in morphine- and cocaine-reinforcing properties suggests specific functions of CREB in the reward circuitry that can distinguish not only types of drugs (cocaine vs morphine) but properties of drugs (aversion vs reinforcement). Compelling evidence indicates that one of the major neural substrates for drug reinforcement 
is the mesolimbic dopamine system; however, identification of specific drug targets within this system is less clear. Cocaine acts to elevate dopamine in the nucleus accumbens, an area involved in reward function. In contrast, opiates appear to have several sites of rewarding action in addition to the nucleus accumbens, such as the ventral tegmental area, lateral hypothalamus, hippocampus, and periaqueductal gray (Wise, 1998). Opiate injections into the VTA elicit reward and elevate NAc dopamine. Tonic inhibition of VTA dopaminergic neurons by neighboring GABAergic neurons that express $\mu$-opioid receptors provide the neuronal mechanism by which morphine acts to disinhibit dopaminergic cell firing (Kalivas and Stewart, 1991). A reduction of CREB in these GABAergic neurons could prevent the effects of morphine in the cell, thus maintaining the tonic inhibition of VTA neurons and preventing the increase in DA in the NAc, resulting in no reinforcement behaviors. In contrast, the direct effects of cocaine in the NAc may rely on regulation of CREB in postsynaptic neurons that are regulated by dopamine D1 or D2 receptors that are coupled to cAMP-signaling pathways. The role of CREB in this postsynaptic response is not known, although activation of downstream targets such as dynorphin (Carlezon et al., 1998), as well as other yet unidentified genes, represent potential mechanisms of action.

Our results indicate that the activation of CREB has a complex role in the neuroadaptive processes associated with addiction. Using CREB-deficient mice as a model, we have demonstrated for the first time that the reinforcing properties of cocaine and morphine are not achieved through the same molecular mechanism. In addition, we have demonstrated that rewarding and aversive properties of drugs of abuse, in this case morphine, can be separated genetically. These results provide an experimental model for why encounters with drugs of abuse do not have the same outcome in all individuals. In other words, a genetic polymorphism in either CREB itself or its many targets could affect both rewarding and aversive properties of drugs of abuse. In the future, genomic analysis will reveal correlations between these genetic polymorphisms and behavioral responses to drugs of abuse.

\section{REFERENCES}

Blendy JA, Kaestner KH, Schmid W, Gass P, Schutz G (1996) Targeting of the CREB gene leads to up-regulation of a novel CREB mRNA isoform. ЕMBO J 15:1098-1106.

Bonci A, Williams JT (1996) A common mechanism mediates long-term changes in synaptic transmission after chronic cocaine and morphine. Neuron 16:631-639.

Bourtchuladze R, Frenguelli B, Blendy J, Cioffi D, Schutz G, Silva AJ (1994) Deficient long-term memory in mice with a targeted mutation of the cAMP-responsive element-binding protein. Cell 79:59-68.

Carlezon WA, Thome J, Olson VG, Lane-Ladd SB, Brodkin ES, Hiroi N, Duman RS, Neve RL, Nestler EJ (1998) Regulation of cocaine reward by CREB. Science 282:2272-2275.

Chakrabarti S, Wang L, Tang WJ, Gintzler AR (1998) Chronic morphine augments adenylyl cyclase phosphorylation: relevance to altered signaling during tolerance/dependence. Mol Pharmacol 54:949-953.

De Vries TJ, Shoffelmeer ANM, Binnekade R, Mulder AH, Vanderschuren LJMJ (1998) Drug-reinstatement of heroin and cocaineseeking behaviour following long-term extinction is associated with expression of behavioural sensitization. Eur J Neurosci 10:3565-3571.

Delfs JM, Zhu Y, Druhan JP, Aston-Jones G (2000) Noradrenaline in the ventral forebrain is critical for opiate withdrawal-induced aversion. Nature 403:430-434.

Duman RS, Tallman JF, Nestler EJ (1988) Acute an chronic opiateregulation of adenylate cyclase in brain: specific effects in locus coeruleus. J Pharmacol Exp Ther 246:1033-1039.

Falls WA, Kogan JH, Silva AJ, Willott JF, Carlson S, Turner JG (2000)
Fear-potentiated startle, but not prepulse inhibition of startle, is impaired in CREBalphadelta $-/-$ mutant mice. Behav Neurosci 114:998-1004.

Gellert VF, Sparber SB (1977) A comparison of the effects of naloxone upon body weight loss and suppression of fixed-ratio operant behavior in morphine-dependent rats. J Pharmacol Exp Ther 201:44-54.

Giros B, Jaber M, Jones SR, Wightman RM, Caron MG (1996) Hyperlocomotion and indifference to cocaine and amphetamine in mice lacking the dopamine transporter. Nature 379:606-612.

Goeders NE, Lane JD, Smith JE (1984) Self-administration of methionine enkephalin into the nucleus accumbens. Pharmacol Biochem Behav 20:451-455.

Goeders NE, Irby BD, Shuster CC, Guerin GF (1997) Tolerance and sensitization to the behavioral effects of cocaine in rats: relationship to benzodiazepine receptors. Pharmacol Biochem Behav 57:43-56.

Guitart X, Thompson MA, Mirante CK, Greenberg ME, Nestler EJ (1992) Regulation of cyclic AMP response element-binding protein (CREB) phosphorylation by acute and chronic morphine in the rat locus coeruleus. J Neurochem 58:1168-1171.

Horger BA, Shelton K, Schenk S (1990) Preexposure sensitizes rats to the rewarding effects of cocaine. Pharmacol Biochem Behav 37:707-711.

Hummler E, Cole TJ, Blendy JA, Ganss R, Aguzzi A, Schmid W, Beermann F, Schutz G (1994) Targeted mutation of the CREB gene: compensation within the CREB/ATF family of transcription factors. Proc Natl Acad Sci USA 91:5647-5651.

Kalivas PW, Stewart J (1991) Dopamine transmission in the initiation and expression of drug- and stress-induced sensitization of motor activity. Brain Res Brain Res Rev 16:223-244.

Kano T, Suzuki Y, Shibuya M, Kiuchi K, Hagiwara M (1995) Cocaineinduced CREB phosphorylation and cFos expression are suppressed in Parkinsonism model mice. NeuroReport 6:2197-2200.

Koob GF (1996) Drug addiction: the yin and yang of hedonic homeostasis. Neuron 16:893-896.

Koob GF, Wall TL, Bloom FE (1989) Nucleus accumbens as a substrate for the aversive stimulus effects of opiate withdrawal. Psychopharmacology 98:530-534.

Koob GF, Maldonado R, Stinus L (1992) Neural substrates of opiate withdrawal. Trends Neurosci 15:186-191.

Lett BT (1989) Repeated exposures intensify rather than diminish the rewarding effects of amphetamine, morphine, and cocaine. Psychopharmacology 98:357-362.

Maldonado R, Blendy JA, Tzavara E, Gass P, Roques BP, Hanoune J, Schutz G (1996) Reduction of morphine abstinence in mice with a mutation in the gene encoding CREB. Science 273:657-659.

Matsuoka I, Maldonado R, Defer N, Noel F, Hanoune J, Roques BP (1994) Chronic morphine administration causes region-specific increase of brain type VIII adenylyl cyclase mRNA. Eur J Pharmacol 268:215-221.

Miner LL, Drago J, Chamberlain PM, Donovan D, Uhl GR (1995) Retained cocaine conditioned place preference in D1 receptor deficient mice. NeuroReport 6:2314-2316.

Nestler EJ, Tallmn JF (1988) Chronic morphine treatment increases cyclic AMP-dependent protein kinase activity in the rat locus coeruleus. Mol Pharmacol 33:127-132.

Nestler EJ, Alreja M, Aghajanian GK (1994) Molecular and cellular mechanisms of opiate action: studies in the rat locus coeruleus. Brain Res Bull 35:521-528.

Phillips TJ, Brown KJ, Burkhart-Kasch S, Wenger CD, Kelly MA, Rubinstein M, Grandy DK, Low MJ (1998) Alcohol preference and sensitivity are markedly reduced in mice lacking dopamine D2 receptors. Nat Neurosci 1:610-615.

Piazza PV, Deminiere JM, Le Moal M, Simon H (1989) Factors that predict individual vulnerability to amphetamine self-administration. Science 245:1511-1513.

Post RM, Weiss SRB (1988) Sensitization and kindling: implications for the evolution of psychiatric symptomatology. Caldwell, NJ: Telford.

Robinson TE, Becker JB (1986) Enduring changes in brain and behavior produced by chronic amphetamine administration: a review and evaluation of animal models of amphetamine psychosis. Brain Res Rev 11:157-198.

Rubinstein M, Phillips TJ, Bunzow JR, Falzone TL, Dziewczapolski G, Zhang G, Fang Y, Larson JL, McDougall JA, Chester JA, Saez C, Pugsley TA, Gershanik O, Low MJ, Grandy DK (1997) Mice lacking dopamine D4 receptors are supersensitive to ethanol, cocaine, and methamphetamine. Cell 90:991-1001.

Shippenberg TS, Heidbreder C (1995) Sensitization to the conditioned rewarding effects of cocaine: pharmacological and temporal characteristics. J Pharmacol Exp Ther 273:808-815.

Silva AJ, Simpson EM, Takahashi JS, Lipp H-P, Nakanishi S, Wehner JM, Giese KP, Tully T, Abel T, Chapman PF, Fox K, Grant S, Itohara S, Lathe R, Mayford M, McNamara JO, Morris RJ, Picciotto M, Roder J, Shin H-S, Slessinger PA, Storm DR, Stryker MP, Tonegawa S, Wang 
Y, Wolfer DP (1997) Mutant mice and neuroscience: recommendations concerning genetic background. Neuron 19:755-759.

Sora I, Wichems C, Takahashi N, Li XF, Zeng Z, Revay R, Lesch KP, Murphy DL, Uhl GR (1998) Cocaine reward models: conditioned place preference can be established in dopamine- and in serotonintransporter knockout mice. Proc Natl Acad Sci USA 95:7699-7704.

Stewart J, Badiani A (1993) Tolerance and sensitization to the behavioral effects of drugs. Behav Pharmacology 4:289-312.

Stinus L, Le Moal M, Koob GF (1990) Nucleus accumbens and amygdala are possible substrates for the aversive stimulus effects of opiate withdrawal. Neuroscience 37:767-773.

Terwilliger RZ, Beitner-Johnson D, Sevarino KA, Crain SM, Nestler EJ (1991) A general role for adaptations in G-proteins and the cyclic
AMP system in mediating the chronic actions of morphine and cocaine on neuronal function. Brain Res 548:100-110.

Vaccarino FJ, Bloom FE, Koob GF (1985) Blockade of nucleus accumbens opiate receptors attenuates intravenous heroin reward in the rat. Psychopharmacology 85:37-42.

Wang L, Gintzler AR (1997) Altered mu-opiate receptor-G protein signal transduction following chronic morphine exposure. J Neurochem 68:248-254.

Wang L, Medina VM, Rivera M, Gintzler AR (1996) Relevance of phosphorylation state to opioid responsiveness in opiate naive and tolerant/dependent tissue. Brain Res 723:61-69.

Wise RA (1998) Drug-activation of brain reward pathways. Drug Alcohol Depend 51:13-22. 